\title{
Equilíbrio e justiça no contrato segundo o paradigma contratual contemporâneo
}

\author{
Roberta Lampert*
}

\section{INTRODUÇÃO}

O presente estudo propõe, para a correta concepção de justiça no contrato, a distinção entre os equilíbrios econômico e normativo na análise da dinâmica contratual. Para construir a proposição e fundamentá-la, pretende-se, antes de mais nada, realizar rápida análise dos contornos dos paradigmas do direito contratual, partindo daquele identificado como clássico, calcado na idéia de autonomia privada, passando-se ao contemporâneo, que se convencionou chamar de paradigma da solidariedade. A partir disso, busca-se identificar a recorrente conceituação de justiça contratual, por parte dos juristas que tratam do tema, como a mera paridade nas prestações para, então, tentar demonstrar que essa posição não só acarreta uma limitada noção de justiça, tendo em conta a racionalidade e a concretização do paradigma da solidariedade, como também determina um inadequado tratamento de certas formas de injustiça nas relações de troca.

\section{DA VONTADE À \\ COMUTAÇÃO: A MUDANÇA DO PARADIGMA CONTRATUAL}

1. O paradigma clássico - o contrato como expressão da vontade

\subsection{A teoria contratual clássica}

A construção da teoria contratual clássica sobre bases jusnaturalistas, acompanhadas de um forte movimento racionalista e aliadas com o individualismo filosófico, resultou em uma concepção que vê o contrato como um meio

\footnotetext{
* Bacharel em direito pela Universidade Federal do Rio Grande do Sul, Assessora de Desembargador no Tribunal de Justiça e aluna da Escola Superior da Magistratura.
} 
para o exercicio do poder de autolimitação da liberdade individual. ${ }^{1}$

A expressão sublinhada e utilizada para sintetizar o conceito de contrato fundado pelo paradigma clássico, em uma análise mais detida, revela mais do que enuncia a reunião das palavras que lhe dão forma. É por seu exame mais pormenorizado, portanto, que se pretende extrair os fundamentos e preceitos da doutrina contratual clássica para exposição no presente trabalho.

$\mathrm{O}$ ato de contratar sempre esteve ligado à noção de obrigar-se. E obrigarse para o pensamento oitocentista, mais do que nunca, significava restrição à liberdade. Devido às bases jusnaturalistas do direito moderno dos contratos, a liberdade individual era ao máximo exaltada, de forma que qualquer limitação somente poderia provir do consentimento do indivíduo: solus consensus obligat. Esta premissa, na qual se assenta o paradigma clássico, é contribuição dos expoentes da Escolástica tardia, Guillaume d'Occan e Duns Scott, que, ao procederem a uma releitura do direito natural aristotélico, atentaram que o indivíduo é um ser livre em seu estado de natureza e, com base nisso, passaram a sustentar que nada poderia restringir tal liberdade, senão o seu consentimento. $^{2}$

O contratar, portanto, passa a ser visto como produto de um consenso, ou seja, um encontro de vontades voltadas a gerar efeitos obrigacionais. E por a restrição à liberdade individual advir tão somente do consentimento, isto é, da vontade do indivíduo, dadas as concepções da época acerca do homem e de sua relação com o Estado, tal autolimitação passa a ser tida como um poder. Daí o contrato poder ser visto como um meio para o exercício do poder de autolimitação da liberdade individual.

A conexão do contrato com tal visão de um indivíduo soberano, dispondo de sua própria liberdade segundo a sua vontade e a identificação disso como um poder acaba por reduzi-lo a um acordo de vontades. ${ }^{3} \mathrm{E}$, dessa forma, a vontade, então vista como expressão do homem e de sua liberdade, representada pela noção de autonomia da vontade, ${ }^{4}$

1 GOMES, Orlando. Contratos. 8. ed. Rio de Janeiro: Forense, 1981.p. 18.

2 MARTINS-COSTA. A noção de contrato na história dos pactos. Revista dos Tribunais, São Paulo, p. 497-513, 1995. Edição em homenagem a Carlos Henrique de Carvalho: o editor dos juristas, p.501.

3 GOMES, Contratos, p. 18.

$4 \mathrm{O}$ poder reconhecido ao indivíduo de auto-regular seus interesses é, mais apropriadamente, designado autonomia privada. O termo autonomia da vontade está associado à concepção voluntarista de contrato e somente nela encontra, destarte, sentido. Por estar-se tratando do paradigma clássico nesse ponto do texto, optou-se por utilizar tal expressão. Sobre a diferenciação entre os termos, NEGREIROS, Teresa. Teoria do 
passa a ser o elemento central do conceito moderno de contrato.

A liberdade, por sua vez, ponto de partida teórico e, portanto, justificação para a exaltação dessa vontade acaba por ter sua importância atenuada, o que fica evidenciado por sua funcionalização, perpetrada pelo paradigma clássico. Convém destacar que o sentido de funcionalização ora empreendido não encontra relação com o que se denomina "concepção funcionalista" de contrato e de direito privado, a qual concebe as instituições deste como instrumentos para a persecução de objetivos socialmente desejáveis. ${ }^{5}$ A funcionalização praticada pelo paradigma voluntarista, que ora se propõe, ao contrário, é mais esvaziada, pois não persegue e sequer elege fins maiores, o que vem a propósito da pretensão de neutralidade esposada por essa concepção de direito privado do século XIX, ${ }^{6}$ que dispunha de um complexo ético ou de uma tábua axiológica um tanto débil. O sentido de funcionalização empregado é apenas o de utilização em função de ou a serventia de algo. Assim a funcionalização que se sugere realizada pelo paradigma voluntarista, é a utilização da liberdade a serviço da vontade e, por isso, o abrandamento da importância daquela em contrapartida à exaltação desta. É o que se extrai do conceito apresentado de contrato como meio para o exercício do poder de autolimitação da liberdade individual, considerando o anteriormente exposto.

A consagração do paradigma contratual sobre as bases do jusnaturalismo, de forte cunho racionalista e individualista, que determinou a concepção de contrato acima examinada, não só resultou na exaltação da vontade como seu eixo central, como também firmou uma visão de indivíduo coerente com seus pressupostos teóricos.

Não só a lógica jusnaturalista, mas todo o sistema de idéias políticas e filo-

contrato: novos paradigmas. Rio de Janeiro: Renovar, 2002, p. 2-4 e MARTINS-COSTA, Judith. Mercado e solidariedade social entre cosmos e taxis: a boa-fé nas relações de consumo. In: MARTINS-COSTA, Judith (Org.). A reconstrução do Direito Privado: reflexos dos princípios, diretrizes e direitos fundamentais constitucionais no direito privado. São Paulo: Revista dos Tribunais, 2002, p. 611-661.

5 MICHELON, Cláudio. Um ensaio sobre a autoridade da razão no direito privado. Revista da Faculdade de Direito da Universidade Federal do Rio Grande do Sul, Porto Alegre, v.21, p. 101-112,2002 e WEINRIB, Ernest J. The idea of private law. Cambridge: Harvard University, 1995, p. 4.

6 Sob o prisma do paradigma clássico, às relações contratuais, assim como às relações de mercado não interessa qualquer questão relacionada à ordem social, a exemplo, as diferenças socioeconômicas entre os contratantes. A pretensão de neutralidade do direito contratual clássico consiste, então, na abordagem abstrata que este paradigma aplica ao contrato, tido como um acordo de vontades entre sujeitos abstratos, reduzidos à sua capacidade negocial. (NEGREIROS, op. cit., p. 298-310). 
sóficas vigorantes à época, era baseado na exacerbação da liberdade individual. O indivíduo se impõe perante o Estado e o repele reduzindo-o. Ao Estado apenas opõem-se deveres, enquanto aos indivíduos atribuem-se direitos. Como bem ressalta Teresa Negreiros em sua obra, "[...] superase o Estado absoluto; ergue-se o indivíduo absoluto". ' A reação é claramente desmedida, pois dá lugar à absolutização da vontade individual.

O paradigma voluntarista, tendo surgido em meio a este cenário, embalado pela matriz teórica do jusnaturalismo, assentou sua doutrina contratual em uma visão abstrata e redutora do indivíduo. A lógica oitocentista concebe o sujeito contratante isolado em sua existência, prescindindo de qualquer identificação do seu meio social. Às relações contratuais, tal concretização não importa, de modo geral, todos são livres e iguais da mesma forma.

Tampouco há a consideração do outro, o que impede a constatação de quaisquer diferenças entre os indivíduos por ser irrealizável a comparação. Desconhece-se os conceitos de poder negocial, vulnerabilidade ou necessidade, $o$ indivíduo é nada mais que um ser dotado de capacidade negocial. ${ }^{8}$ É correto afirmar que a teoria contratual clássica lança mão de uma presunção de igualdade entre os contratantes, contudo, no intuito de melhor compreender-se o significado e o alcance dessa asserção, é preciso ter presente que, antes de presumir uma paridade entre dois sujeitos contratantes, a doutrina oitocentista sequer conhece a alteridade.

$O$ indivíduo para o paradigma voluntarista, assim, em razão da extremada abstração adotada em nome da liberdade e da vontade, era um ser atomizado $^{9}$ e desconectado de sua comunidade, ${ }^{10}$ contando com apenas uma representação; era, portanto, um indivíduo, ou melhor, o indivíduo, o contratante, um ser livre e capaz de auto-regular seus interesses.

\subsection{A Justiça no paradigma clássico}

$\mathrm{Na}$ doutrina contratual oitocentista, a justiça é intrínseca ao modelo. Por força da noção de autonomia da vontade e, ainda, por essa vontade, como expressão da liberdade do homem, ser inatingível, a justiça limitava-se ao brocardo qui dit contractuel, dit juste."

7 NEGREIROS, Teoria..., p. 16.

8 Expressão de Ibidem, p. 18.

9 Ibidem, p. 12.

10 MARTINS-COSTA, Judith. Sobre o principio da insolidariedade: os cumes das montanhas e os universos submersos. Texto ainda no prelo, a ser publicado em livro em homenagem a Friedrich Muller.

11 MARTINS-COSTA, Judith. Crise e modificação da idéia de contrato no direito brasileiro. Revista da Ajuris, Porto Alegre, v. 19, n. 56, p. 56-86, nov. 1992, p. 58. 
Não há, portanto, um parâmetro concreto de justiça. No paradigma clássico, a escolha (vista como ato de escolher) é valorada de forma independente do seu conteúdo. ${ }^{12}$ Justo é aquilo que for expressão da vontade, isto é, aquilo que for pactuado, não importando o quê, mas como.

Não há averiguação substancial de igualdade ou equilíbrio, nem entre as partes, pois estas são presumivelmente iguais, nem sobre o conteúdo da relação contratual, pois fruto da vontade, é necessariamente justo.

A justiça, no paradigma clássico, tendo em vista o seu critério atrelado à vontade, é, portanto, exterior e posterior. Exterior porque o exame do justo sequer adentra na relação contratual, haja vista que tal análise se restringe à averiguação da atuação da vontade do indivíduo, mas jamais do seu conteúdo. Em suma, o exame de justiça fica atrelado à vontade e é impedido por ela de entrar na relação contratual. A justiça, é, ainda, posterior, em razão do mínimo de concretização desse critério, que impede uma afirmação anterior do que é justo ao estabelecer que a vontade dos contratantes o revelará quando expressada.
Conforme foi possível perceber pela presente análise, para o paradigma contratual clássico, a justiça da relação contratual perpetrada entre as partes é necessária consequiência do êxito de sua constituição. A justiça foi esvaziada e seu exame tornado inútil. O paradigma voluntarista, ao retirar-lhe a substantivação e reduzir-the a importância, afastou-a da verificação anterior e última da razão de existir do contrato. Segundo a concepção contratual moderna, a justificação da relação privada de troca consiste apenas em servir de meio para o exercício da autonomia privada. ${ }^{13}$

Diante do que foi exposto nessa primeira parte do trabalho, possível concluir que "a excessiva valorização da subjetividade teve por efeito não só afastar as noções de contrato e comutatividade, como conduziu à anulação do indivíduo". ${ }^{14}$

\section{O paradigma da solidariedade} - o contrato como expressão de utilidade e justiça

\subsection{A construção do paradigma}

A realidade requer permanente adequação dos sistemas conceituais. Afirmando-se a historicidade do Direito e,

12 GORDLEY, James. Contract Law in the Aristotelian Tradition. In: BENSON, Peter (Ed.). the theory of contract law: new essays. New York: Cambridge University, 2001, p.267.

13 Para Morton J. Horwitz, a teoria contratual moderna é concebida em reação e como crítica à tradição medieval de justiça substantiva. Segundo este autor, somente no século XIX passou-se a rejeitar a antiga crença de que a justificação da obrigação contratual era encontrada na necessária justiça da troca. (HORWITZ, Morton J. The historical foundations of modern contract law. Harvard Law Review, Cambridge, v. 87, n. 5, p. 917-956, mar. 1974). 14 MARTINS-COSTA, A noção de contrato..., p. 513. 
portanto, a estreita relação que os modelos jurídicos têm com a realidade social, tem-se que estes assumem significações distintas ao longo do processo histórico. Caso uma norma estivesse jungida à sua conformação original, isto é, determinada pelas circunstâncias fático-axiológicas de sua gênese, lhe seria furtada a eficiência social e tornada impossível a realização de seu fim. Um dado modelo jurídico é, pois, resultado da tensão dialética entre um conjunto de circunstâncias e um quadro de valores. ${ }^{15}$ Havendo modificações em seus possíveis suportes fáticos, bem como na tábua de valores sociais; surge a necessidade desse modelo conformarse, tomando a significação adequada.

Tal dinâmica, que marca o normativismo juridico concreto, ${ }^{16}$ não ocorreu de modo diferente com a figura do contrato. Concebido segundo um determinado complexo de fatos e de valores, o modelo contratual moderno, ao longo da sua história, sofreu uma progressiva variação de significados em adequação às exigências fáticas e axiológicas que surgiram.

Passa-se do subjetivo ao objetivo, da exacerbação da liberdade à valori- zação e urgência da segurança e, por fim, da tutela da vontade à tutela da confiança. As primeiras alterações sofridas pelo paradigma contratual marcam o início de um processo de objetivação do elemento volitivo do contrato. ${ }^{17} \mathrm{No}$ século $X X$, este já passa a ser visto como ato social e não mais como ato de vontade, não podendo mais ser considerado como pura expressão da liberdade do indivíduo, mas como meio para que este regule seus interesses na sua vida privada, conforme definiu Emílio Betti. ${ }^{18}$ A ordem social, em cujo tráfico dar-se-ão as contratações, passa a ser considerada, assim como o indivíduo que figura no outro pólo da relação jurídica contratual, o devedor. Pela primeira vez, o destinatário da declaração de vontade recebe relevo a ponto de ter seus interesses tutelados. Surge uma incipiente tutela da confiança em resposta às reclamadas garantias de segurança e estabilidade nas relações negociais.

Há, destarte, um deslocamento da vontade, da psique do indivíduo à sua manifestação exterior, o que configurou um primeiro passo da ordem de mudanças que seguiria. A Teoria Moderna dos

15 Segundo a concepção tridimensional concreta e dinâmica de Miguel Reale sobre a experiência jurídica, a norma surge da tensão entre fato e valor. (REALE, Miguel. Filosofia do direito. 9. ed. São Paulo: Saraiva, 1982).

16 A expressão é de Miguel Reale. (Ibidem, p. 559).

17 Tal processo de objetivação é entendido, por Enzo Roppo, como uma tendência à progressiva redução do papel e da importância da vontade no contrato. (ROPPO, Enzo. $O$ contrato. Coimbra: Livraria Almedina, 1988. p. 297).

18 BETTI apud MARTINS-COSTA, op. cit., p. 508-509. 
Contratos, dessa forma, passa a adequar-se à sociedade que the confere razão para existir.

O sistema teórico oitocentista, que, baseado na igualdade formal das partes, sustentava que a liberdade dos indivíduos no contratar asseguraria um pacto justo, foi desmentido pela realidade. Os indivíduos não eram iguais e sua desigualdade era apenas acentuada no decorrer da história, o que tornava a sua liberdade de contratar cada vez mais mitigada. Essa realidade, associada ao crescente processo de massificação social, atingirá o direito das obrigações ocasionando uma crescente estandardização e despersonalização das relações privadas de troca, o que, por sua vez, estimulará o abuso da disparidade dos poderes negociais, intensificando as iniciais desigualdades e limitada liberdade.

As relações contratuais efetivamente engendradas pelos indivíduos não refletiam aquilo que o esquema clássico esperava. Os contratos, devido às desigualdades sociais, não correspondiam à vontade das partes e suas condições não retratavam uma limitação voluntária e querida de suas liberdades. Dessa realidade surgem problemas, aos quais a disciplina contratual oitocentista não pôde oferecer tratamento adequado.

Tendo em conta as suas bases conceituais, seria mesmo, para esse paradigma, impossível apresentar um regramento adequado: qualquer contrato a ele submetido seria encarado como produto da atuação de duas vontades igualmente livres e, ainda que houvesse um flagrante desequilíbrio, ele seria tomado como justo. Resta evidente, assim, que a teoria contratual clássica não encontra mais o substrato social que the deu forma, estando, ao contrário, presente outro contexto fático e axiológico, reclamando por adequada ordenação.

Tal problemática revelou o desacerto das bases sobre as quais se fundou o paradigma voluntarista: a concepção unitária de indivíduo, acompanhada da igualdade presumida entre os contratantes, e a liberdade exaltada, vista exclusivamente in abstracto e, assim, presumidamente determinada por sua vontade soberana.

Com efeito, os problemas postos pelas reais relações privadas puseram à prova a lógica individualista do paradigma clássico, que não resistiu demonstrando-se incapaz de regular uma realidade marcada por desigualdades sociais. Thomas Kuhn afirma que "o teste de um paradigma ocorre somente depois que o fracasso persistente na resolução de um quebra-cabeça importante dá origem a uma crise". ${ }^{19} \mathrm{E}$, ao tratar da estrutura das revoluções científicas, ensina que a mudança de um paradigma é deflagrada pela consciência dessa anomalia no sistema, quando se inaugura um período no qual as categorias conceituais são adaptadas e os fatos anteriores reavaliados, de modo a serem encontradas soluções para os problemas

19 KUHN, Thomas S. A estrutura das revoluções cientificas. São Paulo: Perspectiva. 1982, p. 184. 
antes insolúveis, etapa em que se completará a descoberta.

Para superar as dificuldades que deflagraram a revolução, foi preciso uma reconstrução do pensamento científico sobre novas bases. A ciência jurídica buscou apreender o indivíduo como ser concreto e, passando a conhecê-lo, percebe, enfim, sua individualidade. A partir dessa descoberta, alcança-se, finalmente, a noção de que, ao direito dos contratos, não bastando uma concepção abstrata do indivíduo, interessa conhecer os indivíduos e, portanto, sua alteridade e pluralidade.

\subsection{A teoria contratual con-} temporânea

A lógica individualista não resistiu ao ser confrontada com a realidade e teve de ser abandonada. A verdade das relações privadas exigiu um tratamento apropriado e coerente. A solução adequada às questões surgidas em razão das disparidades existentes nas relações contratuais concretas e não resolvidas pelo paradigma clássico não seria encontrada, senão pela construção de uma nova disciplina contratual. Tornou-se evidente a necessidade de um processo de materialização, pois somente por meio deste é que o Direito poderia co- nhecer a realidade das relações sociais $\mathrm{e}$, com isso, os indivíduos nela inseridos.

Surge um sistema que apreende o ser contratante de forma concreta e conhece suas reais necessidades, propondo-se conferir-lhes a tutela jurídica adequada. A opção de conceder relevo à condição social do sujeito destinatário da norma evidencia a construção de um paradigma que se afasta do individualismo e adota a perspectiva de solidariedade social..$^{20}$

A apreensão concreta do indivíduo revelou, ainda, a existência do outro e, com isso, o direito contratual, agora atento a concretizar relações de igualdade substancial, ${ }^{21}$ desde logo firma, entre estes, relações de responsabilidade mútua. ${ }^{22}$

É considerando esses aspectos da mudança da teoria contratual, que se optou por denominar a sua conformação contemporânea como paradigma da solidariedade, solidariedade esta entendida aqui como o sentido mesmo que vincula um indivíduo ao grupo social.

A solidariedade que marca esse novo método expressa a relevância dada ao destinatário da norma e à sua condição 'social, assim como o compromisso com a problemática que desse contexto concreto surge, uma vez reve-

20 NEGREIROS, Teoria..., p.18.

21 A expressão é de Judith Martins-Costa. (MARTINS-COSTA, Judith. Comentários ao novo Cúdigo Civil, Rio deJaneiro: Forense, 2003, v. 5, t. 1: do direito das obrigações, do adimplemento e da extinção das obrigações, p. 7).

22 NEGREIROS, op. cit., p. 19. 
ladas as necessidades reais dos indivíduos. Há, em suma, uma socialização do direito privado em resposta à flagrante inadequação do método tradicional individualista e formalista.

Desde logo é possível perceber que a noção de indivíduo segue sendo determinante ao amoldamento da matriz teórica do paradigma contratual. Não é por outro motivo que o ponto de partida da mudança foi a constatação de que o fracasso em solucionar as questões postas pela realidade social devia-se à concepção abstrata do indivíduo contratante, inserido em relações axiomaticamente vazias e apoiadas em presunções.

O processo de concretização da noção de indivíduo a que se propôs a ciência jurídica contratual partiu da verificação de sua identidade enquanto ser inserido em determinado contexto. Trata-se da visualização da pessoa concreta em suas concretas circunstâncias. ${ }^{23}$ Tal concreção não se limita, portanto, a apreender o contratante considerado em si mesmo, mas como ser social, inserto na complexa realidade social contemporânea.

É a partir da concreção do indivíduo e da consideração de sua relação com o outro que o direito contratual percebeu as identidades dos diversos seres contratantes, concebendo, enfim, as noções de alteridade e de pluralidade. E é a descoberta da existência do outro, ser também dotado de uma individualidade, que tornou possível, finalmente, a percepção da diferença e, com isso, a apreciação da desigualdade. A ciência jurídica contratual procede, portanto, a uma pluralização da subjetividade normativa e passa a conhecer o destinatário da norma, considerado em sua peculiar existência, bem como em sua posição na relação contratual, conhecendo, assim, suas reais necessidades e contingências. Conhecendo a verdade das relações privadas e propondo-se a normatizá-las em face de sua complexidade, esse direito é chamado a exercer tarefas de proteção. ${ }^{24}$

O direito privado, ao seguir essa diretriz de concretude, ${ }^{25}$ volta-se às reais necessidades humanas, cuja satisfação diz com o substrato da dignidade da pessoa. ${ }^{26}$ É dessa forma que a dignidade da pessoa humana se tornará o eixo do novo paradigma, tomando o lugar que antes era ocupado pela vontade. É essa dignidade, portanto, que reformulará o direito dos contratos, se tornando o centro valorativo e normativo do paradigma.

O surgimento de um novo paradigma contratual baseado na solidariedade e centrado na proteção da dignidade da pessoa humana revela a aproximação do direito privado com o direito

23 A expressão utilizada é de Judith Martins-Costa. (MARTINS-COSTA, op. cit., p. 9).

24 NEGREIROS, op. cit., p. 12.

25 A expressão utilizada é de Judith Martins-Costa. (MARTINS-COSTA, Comentários..., p. 8). 26 NEGREIROS, Teoria..., p. 17. 
público, o que é conhecido como processo de constitucionalização do direito civil. ${ }^{27}$ Tal compromisso com a ordem constitucional torna evidente o abandono daquela pretensão de neutralidade antes existente e revela uma identidade de fins entre a Carta Constitucional e a ciência jurídica contratual, qual seja, a construção de uma sociedade justa e solidária.

A mudança de paradigma surge, assim, também evidenciada pela consagração de uma nova ética fundante das relações privadas, ocasionada pela incidência da normativa constitucional no direito dos contratos, o que ocasiona um aumento do seu quadro valorativo. O processo de constitucionalização do direito civil resultou não só na modificação dos seus sistemas conceituais, mas, antes, na alteração de todo o quadro axiológico que informa esse ramo da ciência jurídica.

A trajetória do direito das obrigações rumo a uma nova ética transformou não só os contornos do contrato, mas também a normatividade que o rodeia. A doutrina contratual é embasada em novos valores, como os da dignidade humana e da solidariedade social, e condicionada a observância de novos princípios, inspirados pela incidência da ordem constitucional. ${ }^{28}$
É com o assentamento dessa sistemática que se concretiza a revolução científica pela consagração de um novo padrão teórico, agora centrado em um novo eixo: a dignidade da pessoa humana. Tendo sido afastadas as noçõesbase do paradigma clássico, de igualdade presumida e liberdade exaltada, o contrato, modelo jurídico retirado de sua normatização, adquire novas feições. A partir da materialização do ser contratante e do processo de socialização do direito privado, o contrato já não é mais visto como meio de realização do indivíduo e de atuação da sua liberdade. De instrumento individual, passa a instrumento social, servindo como meio a permitir operações de troca úteis e justas. ${ }^{29}$

Convém salientar que, apesar da teoria voluntarista ter sido superada, a liberdade segue como elemento importante no paradigma. A diferença é que ela é concebida de maneira distinta e não mais como algo sobre o que o indivíduo dispõe soberanamente. Com o surgimento dos novos método e ideologia do paradigma contratual, esta concepção de liberdade cai e são conhecidas as verdadeiras circunstâncias nas quais ocorrem as relações contratuais. A liberdade contratual, é certo, não figura mais como ponto de partida meramente abstrato. Constitui, como

27 A título de exemplo, referência na obra de Teresa Negreiros. (Ibidem, p. 11).

28 Teresa Negreiros, com base no trabalho de Antônio Junqueira de Azevedo, identifica os princípios da boa-fé, da função social do contrato e do equilíbrio econômico como aqueles que compõem essa nova principiologia. (Ibidem, p. 106-114).

29 GHESTIN, Jacques. L'utile et le juste dans les contrats. Archives de Philosophie du Droit, v. 26, p. 35-57, 1981. 
afirmou a filosofia existencialista, uma "liberdade situada". Tampouco, serve de justificação à exaltação de uma vontade absoluta, no entanto, segue funcionalizada. A instrumentalização praticada por este paradigma, ao contrário daquela operada pela doutrina clássica, elege fins maiores a serem perseguidos devido ao aumento do quadro valorativo. A liberdade dessa matriz teórica, portanto, passa a ser vista como instrumento de funcionalização dos novos princípios e persecução de objetivos socialmente desejáveis.

$\mathrm{Na}$ mesma esteira, com a alteração do paradigma contratual, o Princípio da Autonomia Privada, não passa a ser negado, mas afirmado sob outro fundamento. A autodeterminação individual, vista como um poder de regular os próprios interesses e criar normas a si mesmo, segue a transmutação do eixo teórico do paradigma e encontra sua razão não mais na vontade, mas na dignidade da pessoa humana ${ }^{30} \mathrm{~A}$ autonomia privada ganha, portanto, um fundamento constitucional. E é em razão desse mesmo fundamento que, no paradigma da solidariedade, esta autonomia encontra limites com o reconhecimento de uma heteronomia, que, na doutrina contratual contemporânea, atinge o contrato tanto em sua formação, como em seu conteúdo e sua eficácia, representando uma intervenção alheia à vontade dos contratantes.

O paradigma clássico, ao assumir o individualismo filosófico, estabeleceu que as limitações à liberdade apenas teriam origem na vontade do indivíduo. A autonomia, nessa contextualização normativa, sofria, portanto, mínimas intervenções do ordenamento, as quais não deixavam de ter fundamento na vontade do indivíduo, tendo em vista o contrato social que regia a relação existente entre este e o Estado. Essas intervenções, ainda, opunham apenas limites negativos, baseados na ordem pública e nos bons costumes, diretrizes pouco objetiváveis e, em geral, baseadas em idéias morais, políticas, filosóficas e religiosas. ${ }^{31}$ A heteronomia do paradigma contemporâneo representa muito da tarefa de proteção assumida pelo direito privado, pois é sob a forma de normas

\footnotetext{
30 A capacidade de autodeterminação conta com fundamento constitucional, porque é considerada atributo mesmo da dignidade humana, razão pela qual é reconhecida a todos indistintamente. Os cânones da iustiça social, inspirada na filosofia aristotélica, esclarece por que motivo se considera que a autonomia privada é exigência derivada da dignidade da pessoa humana. (BARZOTTO. Luis Fernando. Justiça social: gênese, estrutura e aplicação de um conceito. Revista do Ministério Público do Rio Grande do Sul, Porto Alegre, n. 50, p. 19-56, abr./jul. 2003).

31 E, por isso, salienta Orlando Gomes, essas diretrizes eram bastante sujeitas à manipulação pelo pensamento dominante à época. Ao paradigma clássico, na prática, nunca representaram intervenção relevante à liberdade de contratar, tendo se mostrado, ao fim, insuficientes ao permitirem os abusos que denunciaram a insuficiência dessa matriz teórica. (GOMES, Contrato, p. 29).
} 
abstratas de caráter cogente ou mandamentos judiciais concretos, que o direito contratual fará valer sua nova normatização, centrada na dignidade da pessoa humana e disposta a consagrar o contrato como instrumento da liberdade e da responsabilidade do indivíduo. ${ }^{32}$

E tal sistematização do novo esquema contratual, de afirmação da autonomia privada acompanhada de uma heteronomia atuante, talvez por refletir o cerne do processo de transmutação que houve no paradigma contratual, revela a mais importante faceta da noção de contrato fundada pela nova doutrina: o afastamento do elemento vontade como fator decisivo ao conceito. A extensão do conteúdo da relação obrigacional cessa de ser determinada unicamente pela vontade das partes. ${ }^{33}$

Clóvis do Couto e Silva leciona que a relação obrigacional, como uma totalidade orgânica e uma ordem de cooperação, é "[...] formada de uma unidade que não se esgota na soma dos elementos que a compõem" 34 e que "[...] por ser independente da vontade, a extensão do conteúdo da relação obrigacional já não se mede com base somente nela, e, sim, pelas circunstâncias ou fatos referentes ao contrato, permitindose 'construir' objetivamente o regramento do negócio jurídico, com a admissão de um dinamismo que escapa, por vezes, até mesmo ao controle das partes.". 35

A noção dinâmica de Couto e Silva, que trata da relação obrigacional como um sistema de processos, que se encadeia e se desdobra em direção à satisfação dos interesses de ambas as partes contratantes, em verdade, traduz com primazia a concepção de contrato segundo as novas diretrizes do paradigma contratual da solidariedade: uma relação obrigacional que não mais se esgota no dever de prestar e no correlato direito de exigir a prestação $0^{36}$ e que tem a cooperação como elemento nuclear, pois somente ela tornará possível a efetivação de um contrato útil e justo.

\subsection{A justiça no paradigma da} solidariedade

A desmistificação do paradigma clássico, que atribuía à vontade uma certa função de justiça, dado que se considerava tudo o que fosse voluntaria-

32 GHESTIN, L'utile..., p. 44.

33 Orlando Gomes afirma que a reconstrução do sistema contratual é "orientada no sentido de libertar o conceito de contrato da idéia de autonomia privada e admitir que, além da vontade das partes outras fontes the integram o conteúdo." (GOMES, op. cit., p. 19).

34 SILVA, Clóvis Veríssimo do Couto e. A obrigação como processo. Porto Alegre, 1964, p. 8. 35 SILVA, Clóvis Yeríssimo do Couto e. O princípio da boa-fé no Direito brasileiro e português. In: FRADERA, Vera Maria Jacob de (Org.). O direito privado brasileiro na visão de Clóvis do Couto e Silva. Porto Alegre: Livraria do Advogado, 1997, p. 42.

36 ALMEIDA COSTA, Mário Júlio. Direito das obrigações. 8. ed. Coimbra: Almedina, 2000, p. 63. 
mente estabelecido necessariamente justo, e a consolidação de um novo paradigma, baseado na dignidade humana e proposto à sua tutela, permitiram a reinserção da iustiça na relação contratual.

A concepção social de contrato e o compromisso com a ordem constitucional revelaram que a nova disciplina contratual não se contentaria com a concepção de justiça da doutrina clássica. Desde logo, ao perceber a inadequação do método oitocentista e passar a preconizar o indivíduo concreto, bem como suas reais circunstâncias, o nascente paradigma contratual revelou seu compromisso com uma verdadeira justiça substancial. É dessa forma que foi conferida nova razão de existir ao contrato e, assim, restabelecida sua justificação, baseada na necessária justiça de uma relação de troca.

É a preocupação com o equilíbrio nas relações contratuais que revelará o retorno da justiça corretiva ou comutativa aristotélica ao direito das obrigações. ${ }^{37}$ Aristóteles assentava sua teoria na noção de eqüidade e afirmava que "a justiça nas relações privadas é de fato uma espécie de igualdade". 38 Assim, é o ideal de igualdade substancial que, ao inspirar a noção de paridade, informará a concepção de justiça do paradigma da solidariedade.

Neste novo sistema, há, portanto, um parâmetro concreto de justiça e este é informado pela noção de eqüidade, entendida como igualdade (ou equilíbrio, especialmente ao se tratar das relações de troca). Justa é a relação contratual que apresente um equilíbrio substancial. A ênfase na liberdade sucede a ênfase na paridade. ${ }^{39}$ Como se pode perceber, o conceito de justiça contratual sofre profunda transformação e reaproxima-se da tradição filosófica resgatando a teoria aristotélico-tomista de justiça. ${ }^{40}$

A nova disciplina das obrigações, ao afastar-se da igualdade presumida e da vontade exaltada, tornou possível a averiguação substancial de paridade, no passado tornada inútil pela concepção clássica. A diretriz de concretude e o compromisso do paradigma com a igualdade substancial possibilitaram a verificação de disparidade entre as partes, ao passo que a desmistificação da vontade permitiu a verificação desta disparidade no conteúdo negocial, o qual não mais revelaria necessariamente o iusto, ainda que voluntário.

Ao contrário do que se destacou na análise feita acerca da justiça na teoria

37 Importa anotar que o termo "justiça comutativa" surgiu apenas posteriormente, quando Tomás de Aquino conferiu continuidade à tradição aristotélica acrescentando-lhe elementos da tradição jurídica romana. GORDLEY, Contract..., p. 265.

38 ARISTÓTELES. Ética a Nicômacos. Tradução do grego, introdução e notas Mário da Gama Kury. 3. ed. Brasília: Editora Universidade de Brasília, 2001, p. 97.

39 NEGREIROS, Teoria..., p. 158.

40 Jacques Ghestin sustenta que justiça contratual é uma aplicação particular da justiça corretiva aristotélica. (GHESTIN, L'utille..., p. 46). 
oitocentista, nesse paradigma, ela é interior e anterior. Interior porque é a razão de ser da relação de troca e deve nela figurar, bem como porque $o$ exame do justo adentra a concreta relação existente entre as partes contratantes e considera o seu conteúdo obrigacional. E, ainda, anterior, porque há um parâmetro concreto de justiça a permitir uma afirmação prévia do que é o justo contratual a partir do critério aristotélico.

A justiça contratual não só é tornada relevante no novo paradigma, como é trazida ao interior do seu sistema teórico compondo a sua normatividade e determinando a configuração dos seus conceitos. Exemplo disso é a fundamental modificação da noção de força obrigatória dos contratos, expressada na revisão de seu fundamento, uma vez alterada a justificação das relações privadas de troca.

Jacques Ghestin, ao sustentar a sua tese sobre a justiça e a utilidade nos contratos, destaca que o útil e o justo são os fundamentos da sua força obrigatória: "Le juste et l'utile sont les fondements mêmes de la force obligatoire du contrat, ...". ${ }^{41}$

Inspirado na igualdade substancial, o novo paradigma gerou uma noção de contrato que estabelece a paridade co- mo exigência à sua própria conformação. Destarte, maculada a necessária justiça contratual pela quebra do equilíbrio ou da comutatividade, legitima-se a intervenção estatal para corrigir o distúrbio ocorrido em seu equilíbrio. A obrigatoriedade, antes repousada exclusivamente na vontade das partes, passa a ter como elemento determinante também a justiça contratual. Assim, o contrato é lei entre as partes, desde que condizente com os novos valores e a nova ideologia do sistema.

A alteração do fundamento do princípio da força obrigatória resultou na alteração de um dos seus corolários, a absoluta imodificabilidade do contratado. ${ }^{42} \mathrm{~A}$ intervenção no contrato por meio de ato heterônomo passa a ser imprescindível para o paradigma, que cuida de corrigir a disparidade e restabelecer a relação de igualdade quando esta, eventualmente, restar abalada na relação negocial, em conformidade com os ditames da justiça corretiva.

Conforme se percebe, a atuação da justiça aristotélica passa a ser não só possível, mas decorrência necessária da sistemática do novo paradigma contratual, tendo em vista sua opção por concretizar relações de igualdade substancial. O essencial no contrato deixa de ser a manutenção absoluta da vontade

41 GHESTIN, L'utille..., p. 40.

42 SILVA, Clóvis Veríssimo do Couto e. A teoria da base do negócio jurídico no direito brasileiro. In: FRADERA, Vera Maria Jacob de. O direito privado brasileiro na visão de Clóvis do Couto e Silva. Porto Alegre: Livraria do Advogado, 1997, p. 90. 
inicial e passa a ser a conformidade com a justiça corretiva. ${ }^{43}$

Diante do exposto, é possível concluir que o paradigma da solidariedade, ao proceder a uma apreensão concreta do indivíduo e erigir como seu centro a dignidade da pessoa humana, assumindo tarefas de proteção, não só redescobre o ser contratante conferindo-lhe a devida importância, como reaproxima as noções de contrato e comutatividade.

\section{EQUILÍBRIO E JUSTIÇA NO CONTRATO SEGUNDO O PARA- RADIGMA DA SOLIDARIEDADE}

Após analisar a evolução do paradigma contratual e esquadrinhar a sua disciplina jurídica contemporânea, identificando seu ampliado quadro valorativo e compromisso com o projeto social constitucional, é possível a correta percepção da figura do contrato como ele é, ou deveria ser visto, hoje. Superada essa primeira parte da exposição, destinada ao exame das bases para a análise crítica e proposição que seguem, passa-se ao estudo daquilo que é nuclear ao presente trabalho: a análise do que se entende por iustiça contratual, por meio da contestação de sua identificação tão somente com o equilíbrio econômico do contrato.

\section{O equilíbrio como elemento determinante da justiça contratual}

No âmbito do paradigma da solidariedade, a noção de equilíbrio se revela imprescindível para a correta apreensão da nova racionalidade jurídica da técnica contratual. Quando firmados os novos ideais de igualdade substancial e solidariedade social, restaram superadas as noções de autonomia da vontade e liberdade contratual pretensamente ilimitada como razão explicativa da vinculabilidade contratual. Surge uma nova forma de perceber o contrato, da qual resta inafastável a verificação do "justo concreto". É a noção de equilíbrio que define a concepção de justiça contratual ao reproduzir, na relação entre os contratantes, a idéia de eqüidade ou igualdade, na qual se assenta a teoria aristotélica de justiça.

O equilibrio substancial passa a representar, portanto, a medida de justiça no contrato. Destarte, para uma compreensão correta do justo contratual, é preciso compreender o que é esse equilíbrio, em geral, objeto de escassas referências na doutrina contratualista.

Apesar de a noção de "equilíbrio" ter surgido na antiguiidade, ${ }^{44}$ ela ganhou diferentes significações ao longo da história, em conformidade com o pensa-

43 SILVA, Luís Renato Ferreira. As causas de revisão pelo juiz e o Código de Defesa do Consumidor. Revista da Faculdade de Direito da Universidade Federal do Rio Grande do Sul, Porto Alegre, v. 11, p. 145-164, 1996, p. 151.

44 MACEDO JÚNIOR, Ronaldo Porto. Contratos relacionais e defesa do consumidor. São Paulo: Max Limonad, 1998, p. 89. 
mento dominante a cada época ${ }^{45}$ Esteve bastante presente na teoria aristotélica de justiça ${ }^{46}$ que parte da idéia de igualdade, tida como uma relação entre dois termos e não como uma simples qualidade de igual. ${ }^{47} \mathrm{O}$ filósofo estagirita, ao tratar da justiça nas relações privadas, assevera que a lei deve tratar as partes como iguais atentando apenas ao cometimento da injustiça por parte de uma em detrimento da outra, isto é, para a causação do dano, restando ao juiz realizar a correção desse desequilíbrio buscando restabelecer a igualdade abalada. ${ }^{48}$

No atual estágio da ciência contratual, deve-se considerar que o equilíbrio encontra dois campos de atuação no contrato. Por um lado, este mais evidente, manifesta-se na relação entre as prestações intercambiadas, isto é, na equação econômica da avença. Por outro, revela-se na relação entre direitos e deveres atribuídos a cada parte, ou seja, na carga obrigacional do ajuste.

O desequilibrio econômico pode ser genético ou funcional, de acordo com o momento em que surge, atingindo, portanto, o sinalagma - ou quando da formação e conclusão do contrato ou em momento posterior. A legislação brasileira, confere fundamento às figuras da lesão, ${ }^{49}$ no primeiro caso, e da quebra da base ${ }^{50}$ ou da onerosidade excessiva ${ }^{51}$ no segundo.

O desequilíbrio normativo, por sua vez, diz com outro tipo de sinalagma e requer a visão da relação contratual

45 Nesse sentido, Ronaldo Porto Macedo Jr., que destaca a necessidade do juízo de equilíbrio ser flexível e adaptável à mudança social. (Ibidem, p. 91).

46 Conforme nota, em sua obra, Ernest J. Weinrib: "Because Aristotle conceptualizes violations of corrective justice as disturbances of the equality between the parties, he rests the entire normative weight of corrective justice on that equality. Consequently, we cannot understand the normative character of corrective justice until we elucidate the normative significance of its equality". (WEINRIB, The idea..., p. 76-77).

47 MÁYNEZ, Eduardo García. Doctrina aristotélica de la justicia: estudo, selección e traducción de textos. México: Universidad Nacional Autónoma de México, 1973, p. 80. 48 ARISTÓTELES, Ética..., p. 97.

49 A lesão foi recebida pelo ordenamento brasileiro no Código de Defesa do Consumidor, no art. $6^{\circ}$, inc. V, $1^{a}$ parte, e no Código Civil de 2002, art. 157. (MARTINS-COSTA, Judith. A revisão dos contratos no Código Civil Brasileiro. Rivista Roma e America. Diritto Romano Comune, n. 16,2003, p. 135 et. seq.).

50 A Teoria da Base Objetiva, após ser acolhida e desenvolvida pela jurisprudência dos tribunais brasileiros, restou positivada no Código de Defesa do Consumidor em seu artigo $6^{\circ}$, inciso V, segunda parte. (Ibidem, p. 135 et seq.).

51 A Teoria da Onerosidade Excessiva embasa a redação do artigo 317 do CC/02 e está disciplinada nos artigos 478/480 da mesma lei. (Ibidem, p. 135 et seq.). 
como uma totalidade,,$^{52}$ de modo a se analisar a proporcionalidade entre direitos e deveres dos contratantes na conformação do conteúdo negocial. ${ }^{53}$ Trata-se aqui do fenômeno das cláusulas abusivas, que, por seu fundamento no princípio da boa-fé objetiva, atinge tanto o direito comum, como o direito do consumidor. ${ }^{54}$ Este desequilíbrio, em comparação ao econômico, adquire matiz subjetiva ao considerar-se que sua causa refere-se tão somente à relação existente entre as partes, ou melhor, à prevalência de uma parte sobre a outra ${ }^{55}$ em decorrência da disparidade entre seus poderes negociais, tratandose de caso de abuso de uma situação fática de superioridade. ${ }^{56}$ Assim, se ambos os desequilíbrios podem ser reprimidos pelo princípio da boa-fé objetiva (pela incidência de sua função corretora do desequilíbrio contratual $)^{57}$, este tem seu fundamento de repúdio especificamente em sua normativa, em especial, pela eficácia negativa de sua incidência, a impor limites fundados na proibição genérica de abuso de dada posição jurídica. ${ }^{58,59}$

52 SILVA, C. V. C., A obrigação...

53 De modo semelhante, Fernando Noronha, apoiado em Karl Larenz, chama atenção para o fato de a iustiça substancial objetiva poder ser encarada sob dois prismas: o princípio objetivo de equivalência entre prestação e contraprestação e o princípio da distribuição eqüitativa (ou justa) de ônus e riscos, que, segundo o autor, trata da repartição de benefícios e encargos entre as partes no contrato. (NORONHA, Fernando. $O$ direito dos contratos e seus princípios fundamentais: autonomia privada, boa-fé, justiça contratual. São Paulo: Saraiva, 1994, p. 222-224).

54 Identificam esse fundamento às cláusulas abusivas, entre outros: AMARAL JÚNIOR, Alberto do. A boa-fé e o controle das cláusulas contratuais abusivas nas relações de consumo. Revista Direito do Consumidor, São Paulo, n. 6, p. 27-33, abr./jun. 1993.p. 31 .e SILVA, Luís Renato Ferreira da. Revisão dos contratos: do Código Civil ao Código do Consumidor. Rio de Janeiro: Forense, 2001, p. 52-55.

55 Ibidem, p. 43.

56 A lesão, apesar de visar também ao combate à exploração da contraparte (aspecto subjetivo), é instrumento que se dedica com primazia à tutela da equivalência entre as prestações (aspecto objetivo), face da qual jamais se apartou em sua história.

57 MARTINS-COSTA, Mercado..., p. 611-661.

58 SILVA, L. R. F., op. cit., p. 54.

59 Joaquim de Souza Ribeiro trata com profundidade do que denomina distintas dimensões aplicativas da boa-fé. Destaca o autor que a boa-fé sofreu alteração metodológica e de paradigma normativo ao dar um "salto qualitativo para uma nova função" e evoluir de norma basicamente comportamental, que orienta a conduta das partes, à norma valorativa da posição assumida por estas, que incide diretamente sobre as estipulações contratuais fixando seus limites de validade. (RIBEIRO, Joaquim de Souza. O problema do contrato: as cláusulas contratuais gerais e o princípio da liberdade contratual. Coimbra: Almedina, 1999, p. 550). 
2. O equilíbrio contratual como equilíbrio econômico e normativo noção de justiça contratual apropriada ao paradigma da solidariedade

É possivel que se considere que a diferenciação ora proposta, tida como imprescindível a uma correta apreensão da noção de iustiça contratual, seja uma questão simples e já resolvida em nosso ordenamento a partir da superação do paradigma voluntarista. De fato, é de se admirar que a maioria dos juristas e, entre estes, grandes doutrinadores, ao se dedicarem ao tema do contrato, deixem de considerar tal diferenciação, apresentando uma noção bastante restrita do que seja a justiça contratual. Percebe-se, a partir desse quadro, que o tema, ainda que basilar ao paradigma da solidariedade e essencial à sua realização, carece de tratamento adequado. ${ }^{60}$
Teresa Negreiros, autora de uma das mais apuradas obras que tratam dos paradigmas contratuais, sua evolução e conformação atual, de maneira irrepreensível, aproxima a idéia de justiça contratual a de equilibrio, eqüidade $e$ proporcionalidade. ${ }^{61}$ Ao analisar este equilíbrio, contudo, identifica-o tão somente com a relação entre as prestações recíprocas. ${ }^{62} \mathrm{~A}$ autora torna claro, portanto, que a sua concepção de justiça no contrato é formulada apenas à luz do princípio do equilíbrio econômico ${ }^{63}$, razão pela qual dedica a sua análise exclusivamente ao instituto da lesão, tido por ela como um dos mais perfeitos símbolos de valorização da justiça contratual.

Caio Mário da Silva Pereira, de igual sorte, identifica o problema da lesão como "a questão da justiça no contrato", ${ }^{64}$ chegando a afirmar que a lesão e a justiça se entrelaçam de tal forma que equacionar aquela seria deduzir a fórmula desta. ${ }^{65}$

60 Assim sendo, este estudo não traz a pretensão de revolucionar a concepção de justiça, mas apenas propõe uma análise mais detida sobre a temática, de modo a adequá-la aos preceitos do paradigma contratual contemporâneo, procurando demonstrar a importância de uma correta percepção do equilíbrio contratual para se alcançar uma apropriada noção de justiça nas relações privadas de troca.

61 NEGREIROS, Teoria..., p. 155.

62 O que se percebe claramente a partir desta conclusão: "Com efeito, a noção de equilíbrio no contrato traz para o seio da teoria contratual a preocupação com o justo, entendido tal valor sob a ótica acima definida, isto é, o justo como sendo um critério paritário de distribuição dos bens." (NEGREIROS, Teoria..., p. 166).

$63 \mathrm{O}$ título conferido à seção do capítulo dedicado ao tema da justiça no contrato não deixa dúvidas acerca da correção dessa afirmação: "Justiça no contrato: o princípio do equilibrio econômico". (Ibidem, p. 154).

64 PEREIRA, Caio Mário da Silva. Lesão nos contratos. 6. ed. Rio de Janeiro: Forense, 2001, p. X.

65 No original, "Ora, em última análise, o problema da lesão vai confinar com aquele outro muito mais grave - o da justiça - e de tal forma se entrelaçam que equacionar o primeiro é deduzir a fórmula do segundo.". (Ibidem, p. XIX). 
Nesses casos de limitada noção de justiça, verifica-se, contudo, que não há uma instantânea conexão entre justiça contratual e proporção nas prestações. Não ocorre uma peremptória afirmação e enérgica sustentação dessa tese pela equivalência entre justiça contratual e equilíbrio econômico. Em um primeiro momento, corretamente, é identificada a íntima ligação entre justiça e paridade, equilíbrio; ${ }^{66}$ é somente na percepção do que é esse equilíbrio e, em seguida, na desconsideração de sua faceta normativa que, ao final, opera-se a afirmação de que este equilíbrio é tão somente econômico. ${ }^{67}$ Trata-se, portanto, de uma insuficiente abordagem do tema, que, ao fim, redunda em uma limitada concepção da justiça contratual e não de uma séria proposição por uma concepção mais restrita de justiça, a rechaçar a consideração da proporção entre direitos e deveres assumidos pelas partes como espécie de equilíbrio do contrato.

Ocorre que a concepção de justiça, quando limitada ao equilíbrio econômico, é insuficiente à efetivação da vocação protetiva do paradigma da solidariedade, dado que escapam à sua compreensão situações de injustiça contratual, quais sejam, aquelas em que a paridade nas prestações convive com a disparidade entre direitos e deveres dos contratantes.
São exemplos o caso de um contrato de consórcio que, sem fixar prestação desproporcional ao preço de mercado, impõe cláusula que subtrai a opção de reembolso da quantia já paga pelo consorciado, ou, ainda, no caso de um contrato de compra de produção agrícola, sob a égide do qual não há desvantagem econômica para nenhuma das partes, mas a disparidade entre direitos e obrigações é explícita em cláusula unilateralmente redigida que transfere todos os riscos e responsabilidades ao produtor vulnerável.

Sendo à concepção econômica de justiça impossível a percepção desse tipo de desequilíbrio e dessa modalidade de injusto contratual, sobrevêm duas situações conseqüentes: ou o quadro injusto será ignorado e deixar-se-á de conferir-lhe tratamento, ou o mesmo quadro será erroneamente equiparado a uma disparidade econômica (ainda que haja perfeito equilíbrio entre as prestações) e receberá, por óbvio, o inadequado tratamento.

O compromisso do novo paradigma com a tutela dos contratantes e a promoção de relações substancialmente justas, trouxe à análise a questão da liberdade dos indivíduos e os efeitos que podem acarretar a desigualdade entre eles, ou seja, a disparidade de seus poderes negociais. Essa disparidade

66 Teresa Negreiros, antes citada por sustentar a concepção de justiça que ora se critica, identifica a "noção de paridade como elemento essencial ao conceito de justiça". (NEGREIROS, op. cit., p. 165).

67 A exemplo, é o que ocorre na abordagem realizada por Teresa Negreiros. (Ibidem, p. 154-205). 
geralmente causará o injusto no contrato e tal injusto poderá expressar-se tanto na mácula ao equilíbrio das prestações, como no estabelecimento de um conteúdo negocial manifestamente desvantajoso para a parte débil; ou, ainda, poderá redundar em ambas as manifestações, devendo cada uma receber o tratamento adequado.

A compreensão da justiça contratual como paridade econômica não só evidencia uma noção restrita e insuficiente ao padrão do paradigma da solidariedade, como obsta uma inteira identificação do injusto no contrato, uma vez que formas de injustiça escapam a eșa limitada análise. Tal restrita concepção, que percebe apenas o desequilíbrio na díspar troca de prestações e ignora a repartição de direitos e deveres no contrato, acarreta, portanto, a incompreensão de certas situações que requerem intervenção e, por isso, o seu inadequado tratamento. Verifica-se, destarte, que a noção de justiça limitada ao equilíbrio contratual econômico é desapropriada ao paradigma contemporâneo, posto que impede a realização do seu ideal de justiça substancial.

A consideração da justiça tão somente como a paridade econômica, isto é, da injustiça a ser corrigida como a disparidade nas prestações, restringe, em geral, a análise dos doutrinadores ao instituto da lesão e põe à margem o fenômeno das cláusulas abusivas. Dessa forma, parcela importante da manifestação de injustiça no contrato, expressão do desequilíbrio normativo, é desconsiderada, o que torna insuficiente a atual compreensão da iustiça contratual e impróprio seu tratamento.

Restando marginalizado o fenômeno das cláusulas abusivas ao se tratar da noção de justiça no contrato, o seu tratamento torna-se confuso. Esta é relevante consequiência da posição doutrinária que ora se critica e revela a sua incorreção. Sem conceber a faceta normativa do equilíbrio contratual e limitar sua visão de paridade e, portanto, de justiça, ao equilíbrio econômico, a doutrina encontra dificuldades em distinguir, no âmbito das relações de consumo, o fenômeno das cláusulas abusivas e a figura da lesão, o que determina a dispensa de um tratamento inadequado. Esta confusão entre lesão e abusividade é tão reveladora do desajuste da limitada noção de equilíbrio contratual segundo o paradigma da solidariedade, que o tratamento dessas duas questões, isto é, de uma e outra diferenciação se confundem.

Dessa forma, a desconsideração do equilíbrio contratual normativo não só ocasiona uma insuficiente concepção de justiça, como impede a efetivação dos objetivos de justiça substancial do novo paradigma contratual em razão da falta de adequação no tratamento do injusto.

A exemplo, Anelise Becker, que, por conceber a justiça contratual como o equilíbrio patrimonial da avença ${ }^{68}$ afirma

68 Posição que se evidencia nesta afirmação: "Nesse sentido compreende-se hoje a iustiça contratual, que exige que o contrato não destrua o equilibrio que existia 
que "[...] não há como estabelecer uma diferença necessária entre cláusulas abusivas e lesão" e ressalva:

\section{[...] ainda que viável uma tal distinção, entre nós, diante do regime da lesão instituido por nosso Código de Defesa do Consumidor, não apresentaria interesse significativo, pois, da ma- neira como se encontra redigido, esse Código necessariamente inclui a lesão entre as cláusulas abusivas. ${ }^{69}$}

A autora fundamenta essa afirmação no $\S 1^{\circ}$ do art. 51 do Código de Defesa do Consumidor, que define "vantagem exagerada" para o fornecedor como aquela que "restringe direitos ou obrigações fundamentais inerentes à natureza do contrato, de tal modo a ameaçar seu objeto ou o equilíbrio contratual" (inciso II), ou que "se mostra excessivamente onerosa para $o$ consumidor, considerando-se a natureza e o conteúdo do contrato, o interesse das partes e outras circunstâncias peculiares ao caso" (inciso III). ${ }^{70}$
Por entender que o equilíbrio contratual se restringe ao plano econômico, Anelise Becker vê, em tais disposições, um fundamento para o entendimento de que não há como e não há porque fazer uma distinção entre o instituto da lesão e o fenômeno das cláusulas abusivas. Porém, ao contrário do que sustenta a autora, é possível e necessário estabelecer tal diferenciação, tendo em vista que se trata de duas formas de injusto no contrato a requererem tratamento distinto.

Para o bom entendimento dessa distinção, é preciso apenas bem compreender o equilíbrio contratual e suas formas de manifestação. Ela se torna possivel, portanto, com a clara apreensão de que o instituto da lesão encontra relação com o equilíbrio econômico no contrato, manifestado pela proporção entre as prestações, ao passo que as cláusulas abusivas referem-se ao equilíbrio normativo, revelado na conformação obrigacional da avença. Anelise Becker somente afirma que não há

anteriormente entre os patrimônios, o que implica que cada uma das partes receba o equivalente ao que haja dado, exigência que será mais rigorosa naqueles campos da vida em que gravemente comprometido o equilíbrio de forças entre co-contratantes." (BECKER, Anelise. Teoria geral da lesão nos contratos. São Paulo: Saraiva, 2000, p. 58).

69 Ibidem, p. 106.

70 Caio Mário da Silva Pereira, em sua obra Lesão nos Contratos, apesar de sustentar a concepção restrita de justiça contratual ora criticada, não vai tão longe ao realizar semelhante análise, identificando estritamente a previsão da lesão no CDC em seu artigo $6^{\circ}$, inciso V. Não deixa, ainda, de destacar o tratamento diferenciado a esse instituto referindo que a lesão não conduz necessariamente à invalidade do contrato, mas autoriza a sua sobrevivência com redução de proveito. Ao comentar as práticas (art. 39, CDC) e cláusulas abusivas (art. 51, CDC), apenas refere uma "aproximação notória" entre a figura da lesão e da abusividade. (PEREIRA, Lesão..., p. 210-213). 
como se operar a diferenciação entre as figuras das cláusulas abusivas e da lesão, porque, preliminarmente, sua concepção restrita de justiça contratual a impede de perceber com clareza as diferentes formas de manifestação do desequilíbrio que cada uma expressa. ${ }^{71}$ Considerando-se a distinção entre os equilíbrios contratuais, portanto, tornase possivel a diferenciação entre as figuras da lesão e cláusulas abusivas.

A necessidade da medida é ainda mais evidente, pois não requer que, previamente, o intérprete perceba a existência de dois campos de atuação do equilíbrio no contrato. Trata-se; simplesmente, de atentar aos conceitos de cada figura. A equiparação entre a lesão e a abusividade de cláusulas não é possível e, assim, a sua distinção é imprescindível, porque a presença de cláusulas abusivas em um contrato não tem o condão de torná-lo, como um todo, lesionário. ${ }^{72}$ Tal conduziria ao desvirtuamento do conceito de lesão e significaria afirmar que cláusulas como as que transferem responsabilidade a terceiros, estabelecem a inversão do ônus da prova em prejuízo do consumidor ou possibilitam a violação de normas ambientais, dizem com a relação de proporção entre as prestações assumidas pelas partes, ou seja, com o equilíbrio econômico do contrato. ${ }^{73}$

A distinção entre os desequilíbrios econômico e normativo mostra-se, inserida nessa discussão, ainda mais essencial. A verifícação do equilíbrio ou do desequilíbrio do contrato deve partir da análise do negócio como um todo unitário. A proporção entre as prestações assumidas pelas partes pode restar incólume, enquanto o restante das cláusulas contratuais demonstra uma conformação obrigacional incompatível com a igualdade e, portanto, injusta.

Considere-se, a título de exemplo, os contratos bancários de abertura de conta corrente universitária, que, em geral, são aqueles que oferecem as tarifas mais econômicas do mercado. Não há, por certo, desvantagem econômica

71 Sua visão limitada ao equilíbrio econômico está evidenciada na seguinte afirmação: "Ora, o equilíbrio contratual é dado, fundamentalmente, pelo equilíbrio entre prestação e contraprestação." (BECKER, Teoria..., p. 58).

72 Como quer Anelise Becker quando afirma: "Considere-se, ainda, que um conjunto de cláusulas abusivas pode tornar o contrato, como um todo, lesionário. Assim, é preciso comparar in totum os direitos e obrigações assumidos pelas partes a fim de concluir acerca do equilíbrio ou desequilíbrio do negócio. A verificação do desequilíbrio deve ter em mira a totalidade do contrato, pois a desproporção entre prestação e contraprestação pode não existir, por parecerem equilibradas, e não obstante, haver aproveitamento em virtude de vantagens excessivas nas circunstâncias de tempo, lugar, modo ou outras cláusulas do contrato." (Ibidem, p. 107).

73 Código de Defesa do Consumidor (Lei n. 8.078/90), artigo 51, incisos III, VI e XIV, em ordem de referência no texto. 
ao estudante aderente e, no entanto, é muito comum a oposição de cláusulas que denunciam flagrante desequilibrio entre direitos e deveres das partes, tais como aquelas que implicam renúncia de direitos ou autorizam a outra parte a modificar unilateralmente o conteúdo do contrato. ${ }^{74}$ Em razão da promoção, pelo agente mais forte, de esquema contratual a si excessivamente vantajoso a partir do aproveitamento da sua posição de supremacia na negociação, a igualdade substancial da relação é maculada e, destarte, o pacto é injusto.

O paradigma da solidariedade, sem dúvida, atestaria a ocorrência de injustiça em tal contrato, dado que é contrário aos ditames do seu compromisso com a igualdade substancial e, no entanto, tal conclusão os defensores da justiça restrita ao equilíbrio econômico não poderiam alcançar. A injustiça, portanto, não se restringe ao desequilíbrio econômico, tendo em vista que a atual racionalidade da ciência contratual, de concretude e socialidade, permitiu a percepção de outros meios de mácula à igualdade. Com efeito, tantas serão as modalidades de injustiça contratual, quantas forem as formas de perturbação da igualdade ou equilíbrio existentes em seu âmbito.

A ciência jurídica contratual, tendo assumido a conformação determinada pela racionalidade do paradigma da solidariedade, reconheceu que a atuação da vontade livre não conduz a uma necessária relação justa de troca ao perceber que a desigualdade real entre os indivíduos dá lugar ao abuso de poder econômico, visto como um abuso de situação que permite a uma das partes impor suas condições à outra. ${ }^{75}$ Neste cenário, é inconcebível que não se diferencie os desequilíbrios representados pela lesão e pela abusividade nas cláusulas contratuais.

Em suma, percebe-se que a análise do contrato tendo em vista apenas a noção de equilíbrio econômico impede uma suficiente percepção do injusto que pode lhe acometer, o que ocasiona o inadequado tratamento deste e, portanto, impede a justiça comutativa (corretiva) de ser realizada em sua plenitude. Apenas uma mais aprofundada concepção de equilíbrio contratual, de modo a compreender também a sua faceta normativa, permitiria a efetivação do ideal de justiça que caracteriza o paradigma da solidariedade. Considerando o que já foi exposto acerca dos moldes da atual ciência jurídica contratual, resta evidente que tal limitada análise de equilíbrio e justiça impede, ao final, a correta compreensão do que seja mesmo o contrato segundo $o$ atual paradigma.

74 Código de Defesa do Consumidor (Lei n. 8.078/90), artigo 51, incisos I e XIII, em ordem de referência no texto.

75 GHESTIN, Jacques. Traité de droit civil.Le contrat: formatión. 2. ed. Paris: L.G.D.J., 1988 , p. 685. 
O desconhecimento do equilíbrio contratual normativo revela uma compreensão que ainda se prende aos moldes do paradigma superado. As propostas da nova concepção de contrato, pela apreensão concreta das relações entre os indivíduos e promoção de um parâmetro substancial de justiça, implica que seja revista também essa noção de equilíbrio contratual, sob pena do pensamento científico não acompanhar suas pretensões. De nada adianta pretender promover uma justiça substancial, que alcance as reais injustiças das relações de troca, se antes não se ajusta a própria concepção de paridade contratual.

Jacques Ghestin não só realiza a diferenciação entre os equilíbrios econômico e normativo, como afirma a distinção entre as figuras da lesão e das cláusulas abusivas. O autor corrobora o entendimento de que a interdição dessas cláusulas é reflexo da mudança de racionalidade da ciência jurídica contratual ao afirmar que a sua eliminação implica a rejeição da crença na igualdade abstrata entre as partes, que sustentou o dogma da autonomia da vontade, e a afirmação de uma concepção mais realista do contrato, que considera a desigualdade real existente entre os contratantes, especialmente nas relações de consumo. ${ }^{76}$
Ao tratar da abusividade de cláusulas contratuais, J. Ghestin esclarece a existência de dois critérios essenciais para a sua configuração, o abuso de poder econômico e a vantagem excessiva de uma das partes, e afirma que retrata, mais precisamente, um abuso de situação que permite a uma das partes impor suas condições à outra. ${ }^{77}$ Destaca que não se trata de corrigir um defeito de equivalência do objeto do contrato e seu preço, ${ }^{78}$ mas de eliminar cláusulas acessórias suscetíveis de romper em favor de uma das partes o equilíbrio global da convenção. Afirma, destarte, que tal figura se distingue da lesão "no sentido técnico do termo". 79

O autor conclui, por fim, que há, em ambos os casos, uma ofensa direta à justiça contratual, e que a diferença está no objeto do abuso, que, na lesão, se trata do objeto principal do contrato e valor objetivo das prestações trocadas, enquanto, nas cláusulas abusivas, recai sobre as cláusulas acessórias concernentes, sobretudo, à execução do contrato, tratando-se de um desequilíbrio de direitos e obrigações. ${ }^{80}$

Ronaldo Porto Macedo Jr., ao tratar do tema equilibrio e racionalidade e adentrar na temática da justiça contratual, define o equilíbrio como regra de julgamento do Direito Social ${ }^{81} \mathrm{e}$

76 GHESTIN, Traité..., p. 148.

77 Ibidem, p. 685.

78 Ibidem, p. 675.

79 Ibidem, p. 622.

80 Ibidem, p. 686.

81 MACEDO JÚNIOR, Contratos relacionais..., p. 88. 
medida substantiva de reciprocidade no contrato. ${ }^{82}$ Macedo Jr., diante disso, destaca a importância que a avaliação de justiça tem hoje no âmbito do direito contratual sem fazer referência à proporção entre as prestações intercambiadas, mas genericamente destacando a aplicação do princípio de boa-fé como mecanismo de controle e mitigação das vantagens excessivas, do abuso de poder ou da situação desvantajosa de uma das partes. ${ }^{83}$ Destaca o autor que, na modernidade, diferentemente da concepção platônica, o equilíbrio não define uma essência, mas uma concepção polêmica e pragmática de justiça ${ }^{84}$ Ao expor seu entendimento, explicita que o equilíbrio contratual tem uma dimensão formal, atinente à regularidade das cláusulas obrigacionais, e outra substancial, que se refere à excessiva onerosidade econômica.

Alberto do Amaral Jr., por sua vez, realiza a distinção entre as noções de equilíbrio entre prestações e entre direitos e deveres ao afirmar a impossibilidade de corretamente se compreender a abusividade se esta não for considerada segundo a noção de equilíbrio de posições contratuais, identificável no complexo de direitos e obrigações das partes resultante da celebração do contrato. ${ }^{85} \mathrm{E}$, após analisar o controle das cláusulas abusivas pelo princípio da boa-fé, conclui que o equilíbrio aí preconizado se trata de equilíbrio de posições contratuais, isto é, de equilíbrio da carga obrigacional da avença. ${ }^{86}$

Já Cláudia Lima Marques ressalva explicitamente que a concentração apenas no desequilíbrio econômico do contrato de consumo evidencia uma visão limitada da noção de eqüidade contratual (Vertragsgerechtigkeit) oferecida pelo CDC e pelo princípio da boafé objetiva. ${ }^{87} \mathrm{~A}$ autora define a abusividade da cláusula contratual como o "desequilíbrio ou descompasso de direitos e obrigações típicos àquele contrato específico, a autorização de abuso no exercício da posição contratual preponderante. "88 Cláudia Lima Marques, portanto, conhece a diferenciação entre as distintas manifestações do desequilíbrio contratual aqui proposta e reconhece a importância de tal distinção.

Antônio Junqueira de Azevedo, por sua vez, destaca: "[...] até mesmo no direito brasileiro, em que há confusão entre desequilíbrio econômico e dese-

82 Ibidem, p. 87.

83 Ibidem, p. 89-90.

84 Ibidem, p. 89.

85 AMARAL JÚNIOR, A boa-fé..., p. 31.

86 Ibidem, p. 31.

87 MARQUES, Cláudia Lima. Contratos no Código de Defesa do Consumidor: o novo regime das relações contratuais. 3. ed. São Paulo: Revista dos Tribunais, 1999, p. 134.

88 MARQUES, Contratos..., p. 82. 
quilíbrio de direitos e deveres, as duas hipóteses, in concreto, não podem ser tratadas da mesma forma. $"{ }^{\circ 9}$ Operando sobre essa noção mais aprofundada de equilíbrio contratual, o autor não encontra dificuldades em identificar as distintas manifestações de injustiça no contrato. Aduz que a lesão versa sobre desequilíbrio econômico entre prestação e contraprestação, enquanto as cláusulas abusivas, em princípio, se referem a desequilíbrio de direitos e deveres. ${ }^{90}$

Para apresentar essa compreensão de equilíbrio contratual e destacar sua importância, A. Junqueira de Azevedo lança mão da redação de dispositivos de leis estrangeiras que, ao contrário da legislação brasileira, tratam do tema com clareza demarcando tal diferenciação. Aponta dois trechos do artigo 1.469 do Código Civil italiano, o art. $1.469 \mathrm{bis}$, que define

\begin{abstract}
[...] no contrato concluido entre o consumidor e o profissional, que tem por objeto cessão de bens ou prestação, consideram-se vexatórias as cláusulas que, malgrado boa-fé, determinam, a cargo do consumidor, desequilíbrio de direitos e deveres derivados do contrato.
\end{abstract}

E o art. 1.469 ter, n. 2, que explicita ainda mais:
A avaliação do caráter vexatório da cláusula não diz respeito à determinação do objeto do contrato nem à adequação do correspectivo dos bens e serviços, desde que esses elementos estejam individualizados de modo claro e compreensivel.

E contrapõe, ainda, outros dois trechos do art. L. 132-1 do Code de la Consommation francês, o art. L. 132$1,1^{\mathrm{a}}$ alínea, que enuncia:

[...] nos contratos concluidos entre profissionais e não profissionais ou consumidores, são abusivas as cláusulas que têm por objeto criar, em detrimento do não-profissional ou consumidor, um desequilibrio significativo entre os direitos e obrigações das partes no contrato.

E o art. L. 132-1, $7^{\mathrm{a}}$ alínea, que acrescenta:

A apreciação do caráter abusivo das cláusulas no sentido da $1^{\prime \prime}$ alínea não se refere nem à definição do objeto principal do contrato nem à adequação do preço ou de remuneração do bem vendido ou do serviço oferecido.

Ademais, ainda na esteira do direito comparado, a Diretiva $n .^{\circ} 13$, de

89 AZEVEDO, Antônio Junqueira de. (parecer) A lesão como vício do negócio jurídico. A lesão entre comerciantes. Formalidades pré-contratuais. Proibição de venire contra factum proprium e ratificação de atos anuláveis. Resolução ou revisão por fatos supervenientes. Excessiva onerosidade, base do negócio e impossibilidade da prestação. In Estudos e pareceres de direito privado. São Paulo: Saraiva, 2004, p. 116.

90 Ibidem, p. 115-116. 
5.4.1993, do Conselho da Europa, sobre cláusulas abusivas, corrobora a tese ora esposada, considerando que "a apreciação do caráter abusivo de uma cláusula não deve incidir sobre cláusulas que descrevam o objeto principal do contrato e a relação qualidade/preço do fornecimento ou de prestação"; e, ainda, é clara ao definir que é considerada abusiva a cláusula contratual "que, a despeito da exigência de boa-fé, der origem a um desequilíbrio significativo em detrimento do consumidor, entre os direitos e obrigações das partes decorrentes do contrato."

$\mathrm{O}$ anexo à norma européia contém uma lista indicativa e não exaustiva de cláusulas que podem ser consideradas abusivas e, a exemplo da lista exemplificativa do art. 51 do Código de Defesa do Consumidor, faz menção apenas a disposições que tratam da carga obrigacional do contrato.

A partir do exposto, é possível depreender que a legislação européia assenta com firmeza a diferenciação entre o equilíbrio contratual relativo às prestações intercambiadas e aquele relativo à distribuição da carga obrigacional do conteúdo negocial. A partir da definição de abusividade, firma que esta se vincula tão somente ao desequilíbrio entre direitos e deveres, afastando expres- samente a análise do objeto principal do contrato e da adequação do seu preço.

Em seção denominada "Das cláusulas abusivas", o legislador brasileiro, no Código de Defesa do Consumidor, dedicou extenso dispositivo à exemplificação de cláusulas contratuais nulas de pleno direito, apondo, entre elas, cláusula geral, impressa no inciso IV, da qual se deduz o conceito de abusividade. Esta cláusula é complementada pelo $\S 1^{\circ}$ do mesmo artigo, o qual permite a conclusão de que o núcleo do conceito de abusividade é a noção de desvantagem exagerada a abalar o equilíbrio contratual. ${ }^{92}$ As cláusulas contratuais são inválidas, portanto, quando causarem vantagem exagerada a um dos contratantes em detrimento do outro, revelando-se, por isso, contrárias ao princípio da boa-fé. ${ }^{93}$

O Código de Defesa do Consumidor conhece a diferenciação entre os equilíbrios contratuais que ora se propõe, e sobre ela calca seu sistema, o que se percebe pelas referências apartadas, bem como pelo tratamento distinto que confere ao desequilíbrio econômico (lesão) e ao desequilíbrio normativo (cláusulas abusivas). No entanto, verifica-se que o legislador deixou de assentar com suficiente firmeza essa distinção e ao oferecer cláusula geral de abusivi-

91 Transcrição integral da norma européia. (GRINOVER, Ada Pellegrini et al. Código de Defesa do Consumidor: comentado pelos autores do anteprojeto. 7. ed. Rio de Janeiro: Forense Universitária, 2001, p. 538-547).

92 AMARAL JÚNIOR, A boa-fé..., p. 30-31.

93 AMARAL JUNIOR, Alberto do. Proteção do consumidor no contrato de compra e venda. São Paulo: Revista dos Tribunais, 1993, p. 120. 
dade tão abrangente, no intuito de estender sua proteção, acabou por fazer uma figura abranger a outra. Ao redigir o inciso IV do art. 51 do CDC, complementando-o com o $\S 1^{\circ}$ do mesmo dispositivo, ao contrário do que ocorreu na legislação estrangeira, o legislador brasileiro, não aproveitou a oportunidade para conferir maior rigidez ao sistema e firmar a relação da abusividade com o equilíbrio normativo, tendo apenas utilizado termos como desvantagem exagerada, ameaça ao equilíbrio contratual, vantagem excessivamente onerosa, etc.

A lei francesa, assim como a italiana e a alemã, da mesma forma que a brasileira, definiram a abusividade sobre critérios bastante amplos, a ver, a partir da ocorrência de abuso de poder econômico ou desrespeito aos imperativos da boa-fé, somados à constatação de vantagem excessiva ou desvantagem a uma das partes. ${ }^{94}$ No entanto, não deixaram de apor dispositivo que fixasse com clareza a sua relação com o desequilíbrio normativo, como foi possível perceber acima.

Partindo-se da distinção entre o equilíbrio contratual econômico e o normativo, é possível verificar que, em verdade, o Código de Defesa do Consu- midor apenas permitiu o enquadramento da lesão, como espécie de desequilíbrio que é, entre as cláusulas abusivas, de modo a legitimar, infelizmente, a afirmação de que toda cláusula lesionária é uma cláusula abusiva. Contudo, é imprescindível verificar, pelo menos, que o instituto da lesão é espécie de manifestação abusiva que recebe tratamento específico e não geral, o qual se encontra esculpido no art. $6^{\circ}$, inc. $\mathrm{V}, 1^{\mathrm{a}}$ parte, do mesmo diploma legal. Esse dispositivo erige uma especialização do regulamento da desvantagem exagerada (art. 51, inc. IV, CDC) manifestada pela desproporção nas prestações, que, portanto, deixa de receber o tratamento geral (nulidade), estabelecendo conseqüência específica (modificação da cláusula).

Assim, afasta-se a possibilidade de se sustentar que o Código de Defesa do Consumidor não opera sobre uma diferenciação entre essas figuras e que há "efeitos aparentemente distintos, previstos para a mesma hipótese". ${ }^{95}$ Há, por certo, uma definição do que seja cláusula abusiva por meio de fórmula geral de tal forma aberta, que abrange a figura da lesão, quando não deveria, pois a lei conhece e sugere a sua diferença. ${ }^{96}$

94 SILVA, L. R. F., Revisão..., p. 50-51. MARQUES, Contratos..., p. 408-410. AMARAL JÚNIOR, A boa-fé..., p. 30. GHESTIN, Traité..., p. 684-685.

95 BECKER, Teoria..., p. 106.

96 Cláudia Lima Marques chega a denominar as cláusulas abusivas sancionadas pela nulidade do art. 51 do CDC como cláusulas abusivas stricto sensu, em paralelo às cláusulas que podem ser modificadas por estabelecerem prestações desproporcionais. (MARQUES, Contratos..., p. 406). 
Há, na legislação brasileira, portanto, um conceito de abusividade calcado tão somente na idéia de afronta ao equilíbrio contratual, pelo que se torna possível afirmar que o desequilíbrio é abusividade e que este, então, pode ser relativo à relação entre as prestações intercambiadas, correspondente ao equilíbrio econômico, ou à distribuição de direitos e deveres no conteúdo negocial, correspondente ao equilíbrio normativo.

A falta do legislador, ao conceituar a abusividade sobre a noção de desequilíbrio e fazê-lo de forma muito abrangente, sem explicitar que está a tratar do equilíbrio normativo, não autoriza o jurista a manter restrita sua visão de justiça no contrato, a ignorar a distinção entre este e o equilíbrio econômico. É, em verdade, função mesma da doutrina e do aplicador do direito perceber que a diretriz de justiça substancial é comum entre o paradigma da solidariedade e a lei protetiva do consumidor, e disso depreender, portanto, que a correta compreensão do equilíbrio e da justiça no contrato é imprescindível por exigência de ambos.

Somente tal noção de equilíbrio contratual, que diferencia suas espécies e, portanto, conhece as diferentes formas de injustiça que fazem surgir no contrato, permite uma apreensão correta do que é a justiça contratual segundo a racionalidade do paradigma da solidariedade, impressa na normativa do Código de Defesa do Consumidor, tornando possível a efetivação de sua vocação protetiva e de seus ideais de justiça substancial.

\section{CONSIDERAÇÕES FINAIS}

Em tema de justiça contratual, é imprescindível a identificação das diversas manifestações que o injusto pode tomar na relação negocial, a fim de se lhe conferir o adequado tratamento corretivo. $\mathrm{O}$ paradigma contratual contemporâneo, por ser marcado pelo ideal de igualdade substancial, erige como parâmetro concreto de justiça a noção de equilíbrio, que reproduz, nas relações de troca, a idéia de eqüidade ou igualdade. Por força disso, para uma correta compreensão da justiça contratual, é preciso compreender o que é esse equilíbrio, em geral, objeto de escassas referências na doutrina contratualista.

No atual estágio da ciência contratual, deve-se perceber que o equilíbrio encontra dois campos de atuação no contrato. Por um lado, manifesta-se na relação entre as prestações trocadas, isto é, na equação econômica da avença (equilíbrio econômico); por outro, revela-se na relação entre direitos e deveres atribuídos a cada parte, isto é, na carga obrigacional do ajuste (equilibrio normativo).

Com base nisso, criticou-se a noção de justiça limitada ao equilíbrio contratual econômico, pois desapropriada aos atuais contornos da ciência contratual, de marcada vocação protetiva. Somente uma percepção de justiça transcendente à análise puramente econômica do contrato e ciente da real desigualdade entre as partes, bem como de todas as possíveis formas de desequilíbrio (injustiça) contratual, será adequada à concretude e à pretensão de justiça substancial do paradigma da solidariedade. 


\section{REFERÊNCIAS}

ALMEIDA COSTA, Mário Júlio. Direito das obrigações. 8. ed. Coimbra: Almedina, 2000.

AMARAL JÚNIOR, Alberto do. A boafé e o controle das cláusulas contratuais abusivas nas relações de consumo. Revista Direito do Consumidor, São Paulo, n. 6, p. 2733, abr./jun. 1993.

Proteção do consumidor no contrato de compra e venda. São Paulo: Revista dos Tribunais, 1993.

ARISTÓTELES. Ética a Nicômacos. Tradução do grego, introdução e notas Mário da Gama Kury. 3. ed. Brasília: Editora Universidade de Brasília, 2001.

AZEVEDO, Antônio Junqueira de. (parecer) A lesão como vício do negócio jurídico. A lesão entre comerciantes. Formalidades pré-contratuais. Proibição de venire contra factum proprium e ratificação de atos anuláveis. Resolução ou revisão por fatos supervenientes. Excessiva onerosidade. base do negócio e impossibilidade da prestação. In

Estudos e pareceres de direito privado. São Paulo: Saraiva, 2004.

BARZOTTO, Luis Fernando. Justiça social: gênese, estrutura e aplicação de um conceito. Revista do Ministério Público do Rio Grande do Sul, Porto Alegre, n. 50, p. 19-56, abr./jul. 2003.

BECKER, Anelise. Teoria geral da lesão nos contratos. São Paulo: Saraiva, 2000.

GHESTIN, Jacques. L'utile et le juste dans les contrats. Archives de Philosophie du Droit, v. 26, p. 3557, 1981.
. Traité de droit civil.Le contrat: formatión. 2. ed. Paris: L.G.D.J., 1988.

GOMES, Orlando. Contratos. 8. ed. Rio de Janeiro: Forense, 1981.

GOMES, Orlando; VARELA, Antunes. Direito Econômico. São Paulo: Saraiva, 1977.

GORDLEY, James. Contract Law in the Aristotelian Tradition. In: BENSON, Peter (Ed.). The theory of contract law: new essays. New York: Cambridge University, 2001. p.265-334.

GRINOVER, Ada Pellegrini et al. Código de Defesa do Consumidor: comentado pelos autores do anteprojeto. 7. ed. Rio de Janeiro: Forense Universitária, 2001.

HORWITZ, Morton J. The historical foundations of modern contract law. Harvard Law Review, Cambridge, v. 87, n. 5, p. 917-956, mar. 1974.

KUHN, Thomas S. A estrutura das revoluções científicas. São Paulo: Perspectiva, 1982.

MACEDO JÚNIOR, Ronaldo Porto. Contratos relacionais e defesa do consumidor. São Paulo: Max Limonad, 1998.

MARQUES, Cláudia Lima. Contratos no Código de Defesa do Consumidor: o novo regime das relações contratuais. 3. ed. São Paulo: Revista dos Tribunais, 1999.

MARTINS-COSTA, Judith. A boa-fé no direito privado: sistema e tópica no processo obrigacional. São Paulo: Revista dos Tribunais, 2000. . Comentários ao novo Código Civil, Rio de Janeiro: Forense, 2003. 
v. 5 , t. 1: do direito das obrigações, do adimplemento e da extinção das obrigações.

. Crise e modificação da idéia de contrato no direito brasileiro. Revista da Ajuris, Porto Alegre, v. 19, n. 56, p. 56-86, nov. 1992.

. Mercado e solidariedade social entre cosmos e taxis: a boa-fé nas relações de consumo. In: MARTINSCOSTA, Judith (Org.). A reconstrução do Direito Privado: reflexos dos princípios, diretrizes e direitos fundamentais constitucionais no direito privado. São Paulo: Revista dos Tribunais, 2002. p. 611-661.

. A noção de contrato na hiștória dos pactos. Revista dos Tribunais, São Paulo, p. 497-513, 1995. Edição em homenagem a Carlos Henrique de Carvalho: o editor dos juristas.

A revisão dos contratos no Código Civil Brasileiro. Rivista Roma e America. Diritto Romano Comune, n. 16, 2003.

. Sobre o princípio da insolidariedade: os cumes das montanhas e os universos submersos. Texto ainda no prelo, a ser publicado em livro em homenagem a Friedrich Muller.

MÁYNEZ. Eduardo García. Doctrina aristotélica de la justicia: estudio, selección e traducción de textos. México: Universidad Nacional Autónoma de México, 1973.

MICHELON, Cláudio. Um ensaio sobre a autoridade da razão no direito privado. Revista da Faculdade de Direito da Universidade Federal do Rio Grande do Sul, Porto Alegre, v.21, p. 101-112, 2002.

MURPHY, James Bernard. Equality in Exchange. The American Journal of Jurisprudence, v. 47, p. 85121, 2002.

NEGREIROS, Teresa. Teoria do contrato: novos paradigmas. Rio de Janeiro: Renovar, 2002.

NORONHA, Fernando. $O$ direito dos contratos e seus princípios fundamentais: autonomia privada, boa-fé, justiça contratual. São Paulo: Saraiva, 1994.

PEREIRA, Caio Mário da Silva. Lesão nos contratos. 6 . ed. Rio de Janeiro: Forense, 2001.

REALE, Miguel. Filosofia do direito. 9. ed. São Paulo: Saraiva, 1982.

RIBEIRO, Joaquim de Souza. $O$ problema do contrato: as cláusulas contratuais gerais e o princípio da liberdade contratual. Coimbra: Almedina, 1999.

ROPPO, Enzo. O contrato. Coimbra: Livraria Almedina, 1988.

SILVA, Clóvis Veríssimo do Couto e. $A$ obrigação como processo. Porto Alegre, 1964.

. O princípio da boa-fé no Direito brasileiro e português. In: FRADERA, Vera Maria Jacob de (Org.). $O$ direito privado brasileiro na visão de Clóvis do Couto e Silva. Porto Alegre: Livraria do Advogado, 1997. p. 33-58.

A teoria da base do negócio jurídico no direito brasileiro. In: FRADERA, Vera Maria Jacob de (Org.). $O$ direito privado brasileiro na visão de Clóvis do Couto e Silva. Porto Alegre: Livraria do Advogado, 1997. p. 89-96.

SILVA, Luís Renato Ferreira da. Revisão dos contratos: do Código Civil ao Código do Consumidor. Rio de Janeiro: Forense, 2001. 
As causas de revisão pelo juiz e o Código de Defesa do Consumidor. Revista da Faculdade de Direito da Universidade Federal do Rio Grande do Sul, Porto Alegre, v. 11, p. 145164, 1996.

WEINRIB, Ernest J. The idea of private law. Cambridge: Harvard University, 1995. 